\title{
Intracellular Calcium Levels and Calcium Fluxes in the CA1 Region of the Rat Hippocampal Slice during in vitro Ischemia: Relationship to Electrophysiological Cell Damage
}

\author{
Doug Lobnera and Peter Lipton \\ Department of Physiology and Center for Neuroscience, University of Wisconsin, Madison, Wisconsin 53706
}

Five minutes of oxygen and glucose deprivation (termed "in vitro ischemia") causes long-term synaptic transmission failure (LTF) in the CA1 region of the rat hippocampal slice. Dependence of LTF on cell calcium was tested by generating graded reductions in cell $\mathrm{Ca}$. There was a strong correlation between the average level of exchangeable cell $\mathrm{Ca}$ in $\mathrm{CA} 1$ during ischemia, and the extent of LTF.

In standard buffer, exchangeable cell $\mathrm{Ca}$ in CA1 increased by $35 \%$ after $3 \mathrm{~min}$ of ischemia and remained elevated for the entire $5 \mathrm{~min}$ of ischemia. Unidirectional $\mathrm{Ca}$ influx increased by $35 \%$ during the first $2.5 \mathrm{~min}$ of ischemia and remained at that level for the next $2.5 \mathrm{~min}$. There were no changes in unidirectional $\mathrm{Ca}$ efflux during this period. Thus, the accumulation results from increased influx of $\mathrm{Ca}$.

$\mathrm{Ca}$ influx during the first $\mathbf{2 . 5}$ min of ischemia depended entirely on NMDA channels; it was completely blocked by the noncompetitive NMDA receptor antagonist MK-801. However MK-801 had no effect during the second $2.5 \mathrm{~min}$. This inactivation of NMDA-mediated influx during ischemia appears to result from dephosphorylation. Okadaic acid increased $\mathrm{Ca}$ influx during the second $\mathbf{2 . 5}$ min of ischemia and this increase was blocked by MK-801. The ischemia-induced Ca influx during the second $\mathbf{2 . 5}$ min of ischemia was attenuated $25 \%$ by nifedipine $(50 \mu \mathrm{M})$ and an additional $35 \%$ by the $\mathrm{Na} / \mathrm{Ca}$ exchange inhibitor benzamil (100 $\mu \mathrm{M})$. The AMPA/ kainate antagonist DNQX had no effect on the $\mathrm{Ca}$ influx.

Antagonists were used to relate $\mathrm{Ca}$ influx to LTF. Blockade of enhanced $\mathrm{Ca}$ entry during ischemia in standard buffer (2.4 mM Ca) had no effect on LTF, consistent with total cell Ca prior to ischemia being adequate to cause complete LTF. However, MK-801 strongly protected against LTF when the buffer contained 1.2 $\mathrm{mm} \mathrm{Ca}$, a more physiological level. MK801 combined with DNQX prevented transmission damage in standard buffer. Thus, AMPA/kainate receptor activation contributes to ischemic damage, although not by enhancing Ca entry.

Received Jan. 15, 1993; revised Apr. 29, 1993; accepted May 20, 1993.

We acknowledge the excellent assistance of Sherry Feig in the development and analysis of the micrographs. This work was supported by NSF Grant BNS 9021629

Correspondence should be addressed to Peter Lipton, Department of Physiology, 1300 University Avenue, Madison, WI 53706.

Present address: Department of Neurology, Washington University School of Medicine, St. Louis, MO 63110.

Copyright (c) 1993 Society for Neuroscience $0270-6474 / 93 / 134861-11 \$ 05.00 / 0$
[Key words: calcium channels, desensitization, glutamate, hippocampus, ischemia, NMDA, protein phosphatase, sodium/calcium exchange, ATP, anoxia]

Quite small $(<1 \mu \mathrm{M})$ increases in cytosolic Ca appear to lead to severe damage and cell death in many cell types (Nicotera et al., 1986; Orrenius et al., 1989; Michaels and Rothman, 1990; Smith et al., 1991; Randall and Thaycr, 1992), lending support to the postulated role of increases in cytosolic $\mathrm{Ca}$ in anoxic/ ischemic brain damage (Siesjo, 1988). There are numerous descriptions of increases in whole-cell Ca (Siemkowicz and Hansen, 1981; Kass and Lipton, 1986; Benveniste et al., 1988) and free cytosolic Ca (Silver and Erecinska, 1990; Dubinsky and Rothman, 1991; Uematsu et al., 1991; Kadoyo et al., 1992) during cerebral ischemia. Although there are no quantitative demonstrations that the measured increases are themselves adequate to be toxic, there are results that suggest the importance of $\mathrm{Ca}$ in toxicity. Removal of extracellular $\mathrm{Ca}$ during ischemia, or blockade of the ischemic $\mathrm{Ca}$ increase using pharmacological agents, ameliorates ischemic damage in some systems (Kass and Lipton, 1982, 1986; Roberts and Sick, 1988; Amagasa et al., 1990; Uematsu et al., 1991). Furthermore, inhibition of the Caactivated protease calpain protects against ischemic damage in certain cases (Arai et al., 1990; Lee et al., 1991).

There are several possible mechanisms for the increase in intracellular Ca. They include inhibition of the Ca-ATPase at the plasmalemma, opening of transmitter or voltage-dependent calcium channels, and a net increase in $\mathrm{Ca}$ influx via the $\mathrm{Na} /$ Ca exchanger (Lipton, 1988). All of these mechanisms might well occur during the first few minutes of ischemia as a result of rapid metabolic changes, which include reduced ATP (Albaum et al., 1953; Lipton and Whittingham, 1982), release of glutamate (Benveniste et al., 1984) and other neurotransmitters (Korf et al,, 1988; Globus et al., 1989), membrane depolarization (Rader and Lanthorn, 1989), and increased intracellular $\mathrm{Na}$ (Kass and Lipton, 1982). The observed cell $\mathrm{Ca}$ increase in neuronal cultures appears to result from activation of NMDA receptors (Goldberg et al., 1989) but it is not clear that this is the case in other systems, where effects of anoxia/ischemia are more rapid. Both NMDA receptor-linked and voltage-dependent calcium channel-linked mechanisms appear to contribute to Ca uptake during focal ischemia in situ (Uematsu et al., 1991).

The present studies were partially designed to examine more rigorously the importance of $\mathrm{Ca}$ by determining the quantitative relationship between cell $\mathrm{Ca}$ levels and the extent of damage in the rat hippocampal slice transiently deprived of oxygen and 
Figure 1. Electron micrograph $(25,000 \times)$ of CA1 stratum radiatum from slice incubated in standard buffer. $A$, preterminal axons and/or boutons; $D$, dendrites; $E C S$, extracellular space; $G$, presumed glial profiles; $R$, cross sections of either dendritic or axonal elements.

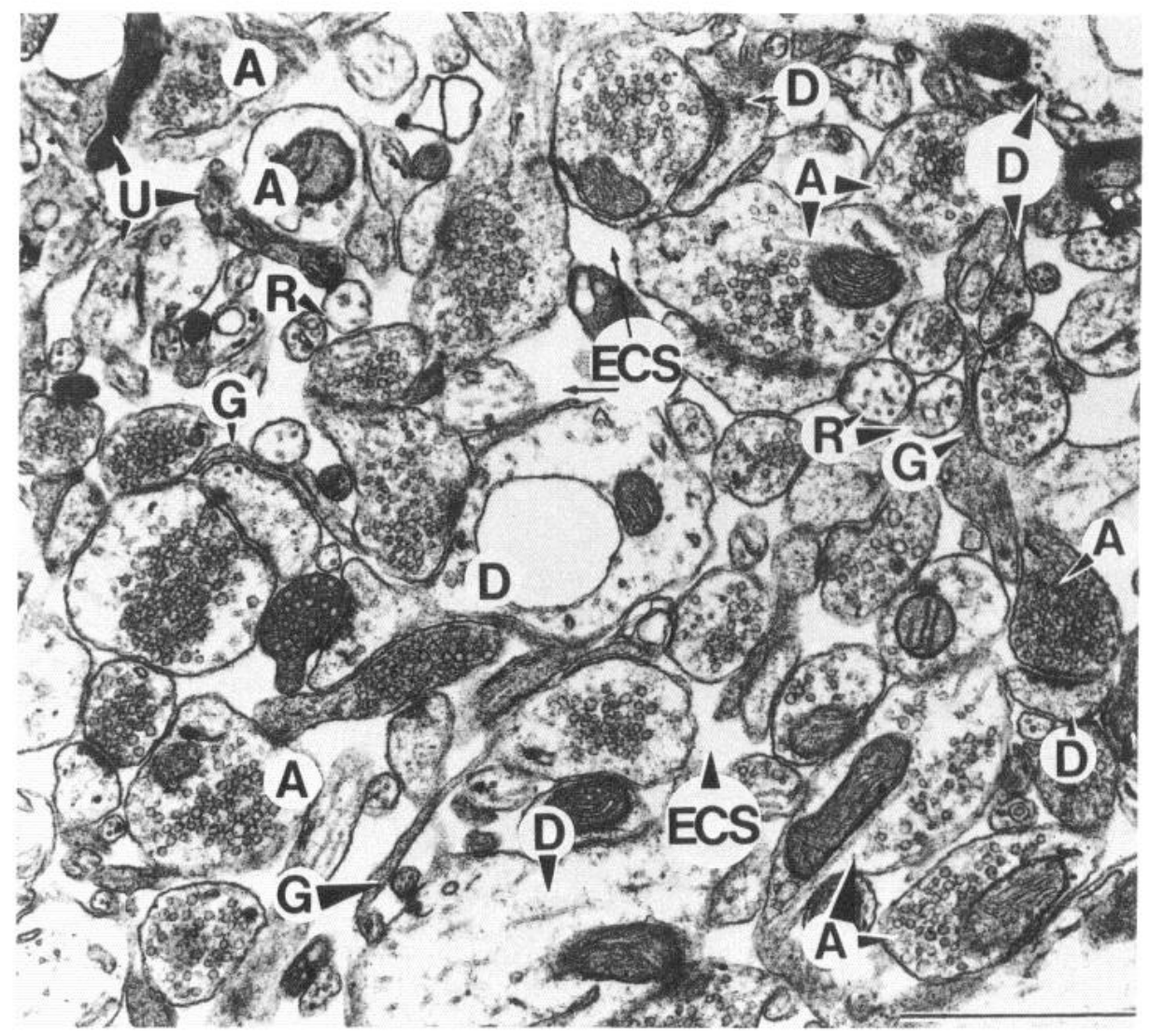

glucose. The mechanisms by which cells in the CA1 hippocampal region accumulate $\mathrm{Ca}$ during this in vitro ischemia, and the relationship of some of these uptake processes to long-term synaptic transmission failure (LTF) were also determined.

\section{Materials and Methods}

Tissue preparation and incubation. Some of the methodology has been described elsewhere (Kass and Lipton, 1982). White male SpragueDawley rats, 70-100 d old, were decapitated without anesthesia. The cerebral hemispheres were rapidly removed and placed in ice-cold standard buffer (see below for composition). The hippocampi were removed and $425 \mu \mathrm{m}$ transverse slices were prepared using a McIlwain tissue chopper. Slices were incubated at $33^{\circ} \mathrm{C}$ for $2-3 \mathrm{hr}$ on nylon bolting cloth platforms, submerged beneath approximately $1 \mathrm{~mm}$ of standard buffer, before beginning each experimental procedure. All experimental procedures were carried out at temperatures between $36^{\circ} \mathrm{C}$ and $37^{\circ} \mathrm{C}$. Procedure for preparation of slices was approved by the University of Wisconsin RARC.

Buffers. Standard buffer contained $124 \mathrm{mM} \mathrm{NaCl}, 3.0 \mathrm{~mm} \mathrm{KCl}, 1.4$ mм KH $\mathrm{PO}_{4}, 1.3 \mathrm{~mm} \mathrm{MgSO}_{4}, 26 \mathrm{~mm} \mathrm{NaHCO}_{3}, 2.4 \mathrm{~mm} \mathrm{CaCl}$, and 4 mM glucose, equilibrated with $95 \% \mathrm{O}_{2}, 5 \% \mathrm{CO}_{2} ; \mathrm{pH}$ was 7.4 . In vitro ischemia buffer was as standard buffer except free of exogenous glucose and equilibrated for $20 \mathrm{~min}$ with $95 \% \mathrm{~N}_{2}, 5 \% \mathrm{CO}_{2}$. Conditions in the presence of this buffer are termed "ischemic" (Whittingham et al., 1984). Reduced $\mathrm{Ca}$ buffers were as standard buffer except $\mathrm{CaCl}_{2}$ was varied to give appropriate $\mathrm{Ca}$ concentrations and no substitution of divalent cations was made. $0 \mathrm{Ca} / 2 \mathrm{~mm}$ EGTA buffer was as standard buffer except $\mathrm{CaCl}_{2}$ was omitted and $2 \mathrm{~mm}$ EGTA was added.

Electrophysiological responses. Following the 2-3 hr preincubation, slices were submerged on a nylon bolting cloth platform in a small chamber (about $5 \mathrm{ml}$ vol) that was perfused with approximately 100 $\mathrm{ml}$ of equilibrated buffer, recirculated at a rate of $60 \mathrm{ml} / \mathrm{min}$. The Schaffer collateral/commissural pathway was activated by bipolar stimulation and recordings were made in the CAl pyramidal cell layer using a tungsten microelectrode (Lobner and Lipton, 1990). Stimulation was continued during the ischemic period. The amplitude of the population spike was used to quantify the transynaptic response (Kass and Lipton, 1982). In the absence of intervention the population spike height generally varied by less than $10 \%$ over $3 \mathrm{hr}$ periods. In experiments using reduced $\mathrm{Ca}$ buffers, slices were returned to normal $\mathrm{Ca}$ buffer following ischemia to measure recovery of the population spike.

Measurement of total cell calcium in the CAI region. Slices were maintained on the same nylon bolting cloth platforms used for preincubation. ${ }^{45} \mathrm{Ca}$, as $\mathrm{CaCl}_{2}(2 \mu \mathrm{Ci} / \mathrm{ml})$, was included in the standard buffer or in some cases in buffers with altered $\mathrm{Ca}$ concentrations, for a total of $50 \mathrm{~min}$. The half-time for ${ }^{45} \mathrm{Ca}$ uptake into the CAl region is approximately $7 \mathrm{~min}$ (Kass and Lipton, 1986), so $50 \mathrm{~min}$ is adequate to allow essentially complete equilibration of the extracellular ${ }^{45} \mathrm{Ca}$ with the exchangeable cell $\mathrm{Ca}$ pool. Exposure to in vitro ischemia was carried out in buffer with the same $\mathrm{Ca}$ concentration and specific activities or, in some cases, in buffer containing no extracellular $\mathrm{Ca}$ or ${ }^{45} \mathrm{Ca}$. In both these conditions, changes in cell ${ }^{45} \mathrm{Ca}$ must reflect changes in total cell exchangeable $\mathrm{Ca}$. At the end of the experiment slices were washed in ice-cold buffer containing $2 \mathrm{mM} \mathrm{LaCl}_{3}$ for $1 \mathrm{hr}$ to remove extracellular ${ }^{45} \mathrm{Ca}$ (Kass and Lipton, 1986). The slices were then frozen in liquid nitrogen and dried under vacuum for $12-18 \mathrm{hr}$, and the CAl region of the lyophilized slices was isolated by microdissection. The dissected region included the pyramidal cell layer, the stratum radiatum, and about half of the stratum lacunosum-moleculare. Dry tissue weights were measured on a microbalance (Cahn) and ranged from 0.05 to 0.10 $\mathrm{mg}$. Tissue was then dissolved in concentrated nitric acid and the radioactivity measured by scintillation counting. Exchangeable tissue $\mathrm{Ca}$ was calculated as (tissue ${ }^{45} \mathrm{Ca}$ )/(specific activity of ${ }^{45} \mathrm{Ca}$ in the loading buffer), and was expressed as $\mathrm{nmol} \mathrm{Ca} / \mathrm{mg}$ dry weight of tissue.

Measurements of calcium influx. Unidirectional influx was approximated by exposing the slices to ${ }^{45} \mathrm{Ca}$ for $2.5 \mathrm{~min}$ and measuring ${ }^{45} \mathrm{Ca}$ accumulation as described for total cell $\mathrm{Ca}$ measurements. Using the brief period of ${ }^{45} \mathrm{Ca}$ uptake provides a measure of $\mathrm{Ca}$ influx that is only slightly contaminated by efflux. The monoexponential equation

$$
\mathrm{Ca}(t)=\mathrm{Ca}(T)(1-\exp (-k t)),
$$

where $\mathrm{Ca}(t)=$ total $\mathrm{Ca}$ taken up at time $t, \mathrm{Ca}(T)=J / k=$ pool size, $J$ $=$ unidirectional influx, and $k=$ efflux rate constant, is able to account for the ${ }^{45} \mathrm{Ca}$ uptake into the CAl region of the rat hippocampal slice, 
with the efflux rate constant of $0.103 \mathrm{~min}^{-1}$ (Kass and Lipton, 1986). It can be calculated from Equation 1 that a $50 \%$ decrease or a $100 \%$ increase in the efflux rate constant would only affect uptake measured during $2.5 \mathrm{~min}$ by $9 \%$ and $11 \%$, respcctivcly. Thus, in the absence of large changes in efflux, the $2.5 \mathrm{~min}$ uptake is a reliable measure of influx.

Measurement of calcium efflux. Slices were equilibrated with ${ }^{45} \mathrm{Ca}$ for $50 \mathrm{~min}$ in standard buffer; slices were then transferred into $0 \mathrm{Ca} / 2 \mathrm{~mm}$ EGTA buffer containing no ${ }^{45} \mathrm{Ca}$ for $2 \mathrm{~min}$ to remove extracellular ${ }^{45} \mathrm{Ca}$. Slices were then exposed to $0 \mathrm{Ca} / 2 \mathrm{~mm}$ EGTA for an additional $0,2.5$, or $5 \mathrm{~min}$ in normoxic or ischemic buffer. ${ }^{45} \mathrm{Ca}$ in the $\mathrm{CA} 1$ region was measured at these three times in different slices.

ATP measurements. Experimental procedures were similar to those for the cell Ca experiments except tissue was frozen immediately after the experiment. The ATP in the CAI region was extracted as described previously (Lowry et al., 1964) and measured using a luciferin-luciferase-based assay (Lust et al., 1981; Kass and Lipton, 1986).

Measurement of areas occupied by different cellular elements in stratum radiatum of $C A 1$. Scmithin scctions were prepared for light microscopy and thin sections were prepared for electron microscopy using standard techniques (Feig and Lipton, 1990). Light microsocopy was used to identify the percentage of the stratum radiatum that was occupied by glial and interneuronal cell bodies. Low-power electron micrographs $(7500 \times)$ were used to measure the percentage of stratum radiatum that was occupied by large longitudinal dendritic profiles (diameter $>1 \mu \mathrm{m})$. High-power $(25,000 \times)$ micrographs (Fig. 1) were used to measure the percentages of the areas occupied by smaller profiles. These included dendrites, presynaptic axons and boutons, cross-sectional profiles that were either pre- or postsynaptic, unidentified elements that included glial profiles, and the extracellular space. Two slices were analyzed in this way. Four micrographs per slice were analyzed at low power and four at high power. The total area per slice analyzed at low power was $7200 \mu \mathrm{m}^{\prime}$ and the total area per slice analyzed at high power was $280 \mu \mathrm{m}^{2}$. Areas of tissue elements were measured using a computerized tracing system (Jandel).

Chemicals. MK-801 [(+)-5-methyl-10,11-dihydro-5H-dibenzo[a,d]cyclohepten-5,10-imine maleate] was obtained from Merck (Rahway, NJ); DNQX (6,7-dinitroquinoxaline-2,3-dione); benzamil, from Research Biochemicals Incorporated (Natick, MA); okadaic acid, from Molecular Probes (Eugene, OR); and DTG [di(o-tolyl)guanidine], from Aldrich (Milwaukee, WI). All other chemicals were obtained from Sigma (St. Louis, MO). All chemicals except calmidazolium, okadaic acid, and benzamil were added to the bathing medium $10 \mathrm{~min}$ prior to ischemia and were present during ischemia. Calmidazolium, okadaic acid, and benzamil were added $30 \mathrm{~min}$ prior to ischemia and maintained during ischemia.

Data presentation. All crror bars represent SEMs. $n=$ number of independent observations. An independent observation was the measurement of an ion concentration, metabolite, or electrophysiological response in one slice. In general, one animal was used for an experiment. For ion and ATP measurements, there were six treatments or incubation times per experiment; four slices were used for each treatment or time. In each experiment there were some slices that were untreated with drugs or ischemia (control normoxia). Values for the other treatments were expressed as percentages of these "control normoxia" values. For electrophysiological measurements up to three different treatments were carried out on slices from one animal. One of these was always a control (no addition) ischemia. Statistical significance of differences between treatments was calculated using Student's $t$ test, unless indicated as analysis of variance with Fisher's least significant difference test.

\section{Results}

Relationship between cell calcium and long-term transmission failure

Ischemic cell damage was assessed as long-term loss of the population spike in the CA1 pyramidal cell layer evoked by stimulation of the Schaffer collateral/commissural pathway (Kass and Lipton, 1982). Five minutes of ischemia caused total LTF; there was no recovery of the population spike after $60 \mathrm{~min}$ of reoxygenation.

If increased cytosolic $\mathrm{Ca}$ is a trigger for LTF, then decreasing the intra- and extracellular sources of Ca during ischemia should protect against the damage. This was tested in two different
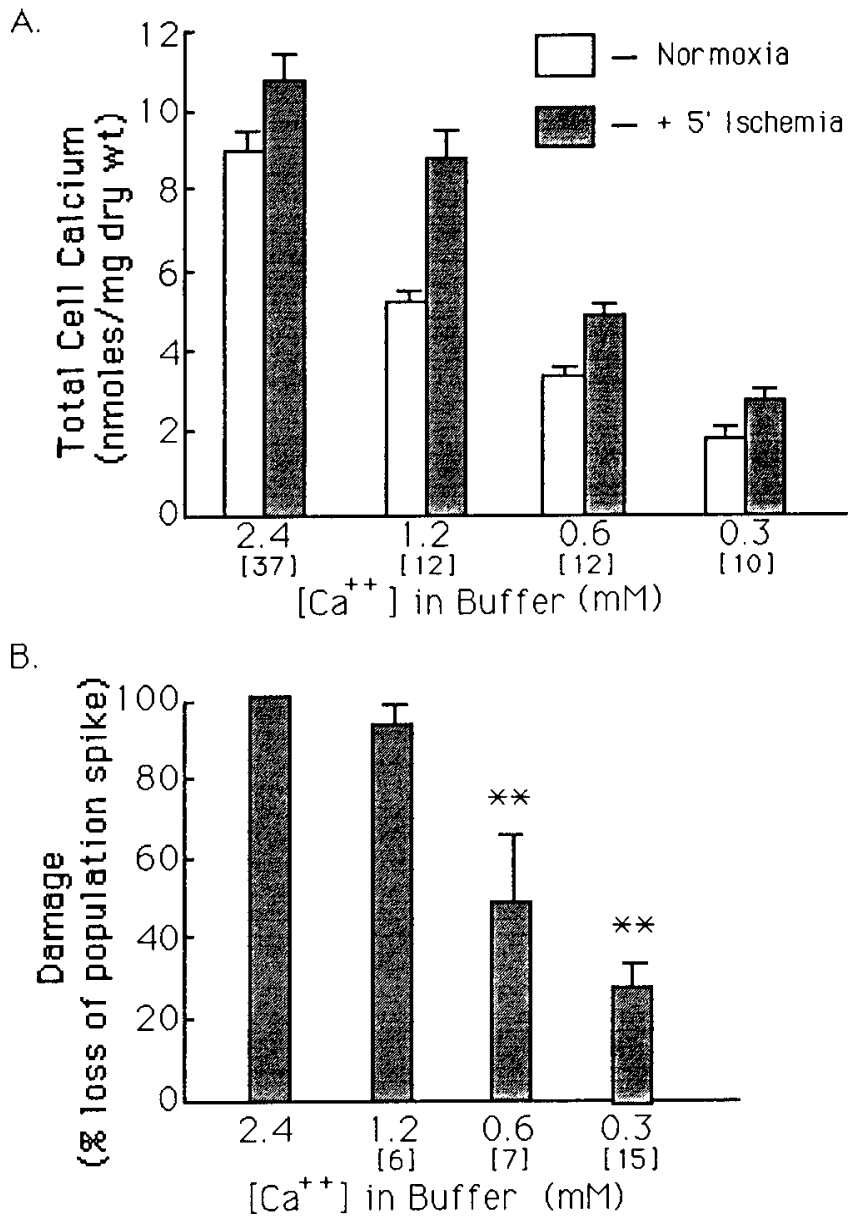

Figure 2. Effects of prolonged exposure to reduced extracellular $\mathrm{Ca}$ on transmission damage and cell calcium. Slices were incubated in modified buffers containing the indicated Ca concentrations for $45 \mathrm{~min}$ prior to $5 \mathrm{~min}$ of ischemia and during the ischemia. In electrophysiological experiments slices were returned to normal $\mathrm{Ca}$ buffer $5 \mathrm{~min}$ after the ischemia in order to allow measurement of recovery. $A$. Cell calcium measured after $50 \mathrm{~min}$ of exposure to ${ }^{45} \mathrm{Ca}$ in different extracellular $\mathrm{Ca}$ buffers. Open bars, normoxic for entire $50 \mathrm{~min}$; solid bars, final $5 \mathrm{~min}$ ischemic. $B$, Effect on population spike. Percentage damage $=(1-P /$ $\left.P_{0}\right) \times 100$, where $P_{0}=$ population spike amplitude prior to reducing extracellular $\mathrm{Ca}$, and $P=$ population spike amplitude measured $60 \mathrm{~min}$ after 5 min of ischemia. ${ }^{* *}$, Significantly different from $100 \%$ damage, $p<0.01$. Numbers in brackets $=n$.

experimental paradigms. In the first, extracellular $\mathrm{Ca}$ was reduced to different levels for $45 \mathrm{~min}$ prior to ischemia as well as during the $5 \mathrm{~min}$ ischemic period. There were marked reductions in intracellular $\mathrm{Ca}$ prior to ischemia and intracellular $\mathrm{Ca}$ increased from this value during in vitro ischemia (Fig. $2 A$ ). Lowering extracellular $\mathrm{Ca}$ to a physiological level, $1.2 \mathrm{mM}$, reduced cell Ca by about $40 \%$, but did not significantly attenuate LTF (Fig. 2B). However, more profound reductions in intracellular $\mathrm{Ca}$ were associated with significant attenuation of LTF (Fig. $2 B$ ).

In another paradigm, tissue was exposed to nominally $\mathrm{Ca}$ free $(0 \mathrm{Ca})$ buffer for different durations prior to the $5 \mathrm{~min}$ of ischemia, and during the ischemia. Figure $3 A$ shows that cell $\mathrm{Ca}$ declined as the time of exposure to $0 \mathrm{Ca}$ increased, and that in all cases it decreased further during the $5 \mathrm{~min}$ ischemic interval. Removing extracellular $\mathrm{Ca}$ only during the $5 \mathrm{~min}$ of ischemia gave slight protection against LTF $\left(0^{\prime}\right.$ in Fig. $\left.3 B\right)$. 
A

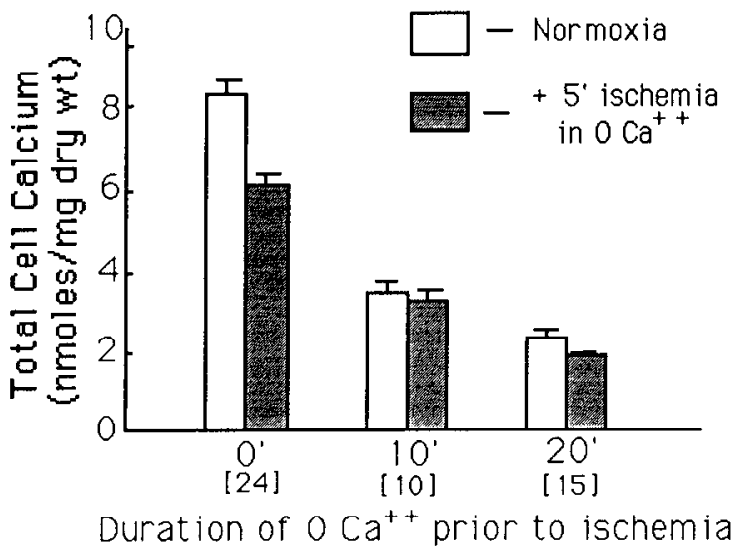

B.

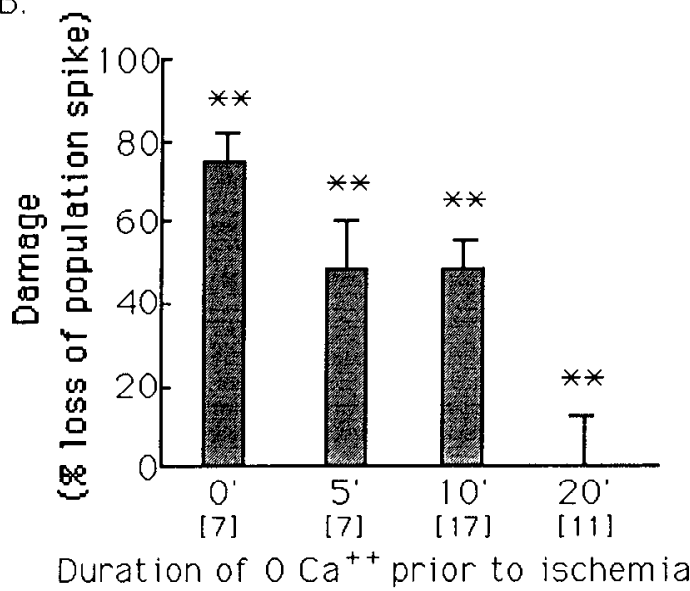

Figure 3. Effects of $0 \mathrm{Ca}$ incubation on transmission damage and cell calcium. Slices were incubated in $0 \mathrm{Ca}$ buffer prior to ischemia for the periods indicated. For electrophysiological studies slices were returned to normal-Ca buffer $5 \mathrm{~min}$ after ischemia. $A$, Slices were incubated in standard buffer with ${ }^{45} \mathrm{Ca}$ for $50 \mathrm{~min}$ followed by varying periods in 0 $\mathrm{Ca}$ buffer containing no ${ }^{45} \mathrm{Ca}$. Open bars, slices removed after duration shown in normoxic buffer; solid bars, slices in ischemic buffer with 0 Ca for an additional 5 min. $B$, Damage to synaptic transmission measured as in Figure 2.

However, when slices were incubated in $0 \mathrm{Ca}$ buffer for periods prior to the ischemia, there was far better protection. Twenty minutes of preincubation in $0 \mathrm{Ca}$ buffer provided full protection against LTF; there was no measurable damage. Figure 4 is a summary of the two studies described in Figures 2 and 3, and also includes a data point showing the effect of exposing slices to $0 \mathrm{Ca}$ buffer containing $2 \mathrm{~mm}$ EGTA for $5 \mathrm{~min}$ prior to and during ischemia. There is a good correlation $(r-0.927)$ between the extent of LTF and the mean level of cell $\mathrm{Ca}$ during the ischemic period over the entire range of cell $\mathrm{Ca}$, regardless of whether there was influx (lowered $\mathrm{Ca}$ ) or efflux (nominally 0 Ca) of $\mathrm{Ca}$ during the ischemic interval.

\section{Effects of lowered $\mathrm{Ca}$ on ATP levels}

A possible explanation for the protective effect of lowered $\mathrm{Ca}$ is that it decreased the rate at which ATP fell during ischemia. Figure 5 shows this was not the case. The two $\mathrm{Ca}$ incubation paradigms that most strongly protected the slice against LTF actually increased the rate at which ATP fell during in vitro ischemia in the CA1 region. This acceleration appears to result

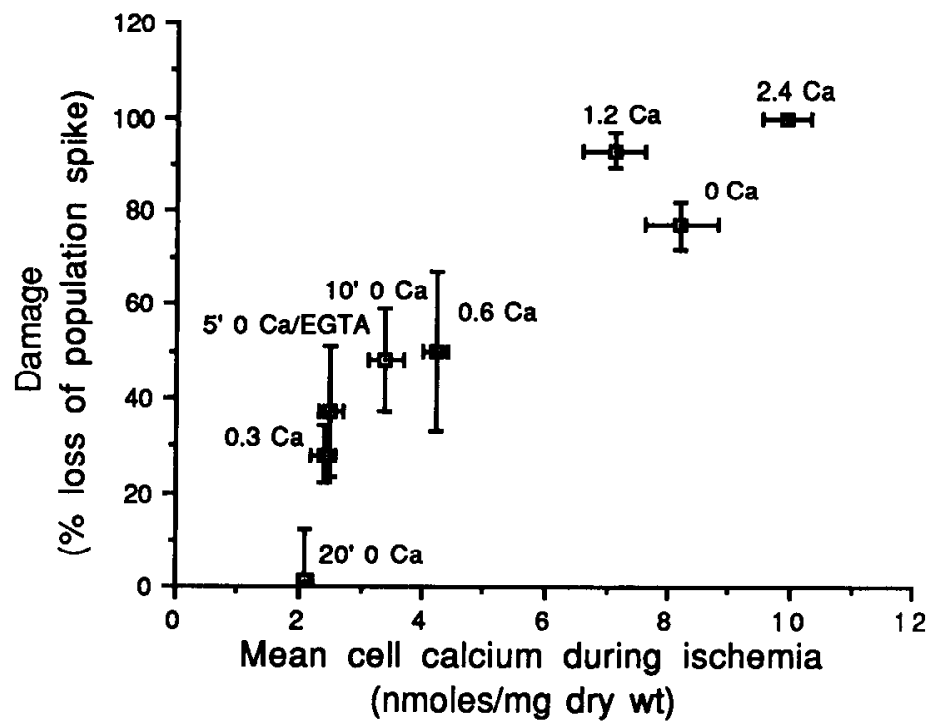

Figure 4. Relationship between transmission damage and cell calcium. This figure was constructed from data in Figures 2 and 3 with addition of one study $\left(5^{\prime} O \mathrm{Ca} / E G T A\right)$. In that study slices were exposed to $0 \mathrm{Ca}$ buffer containing $2 \mathrm{~mm}$ EGTA for $5 \mathrm{~min}$ prior to ischemia, during, and for 5 min after ischemia. Mean cell calcium during ischemia is the average between the cell calcium prior to ischemia and that at the end of ischemia. The linear correlation coefficient for the relationship between I.TF and cell calcium is 0.927 .

from enhanced $\mathrm{Na}$ entry during the ischemia (D. Lobner and P. Lipton, unpublished observations). The 0 Ca paradigm also does not appear to be protective by enhancing ATP recovery after ischemia. ATP levels 10 min following 5 min of ischemia in normal $\mathrm{Ca}$ buffer returned to $73 \pm 3 \%$ of control; in the 0 Ca paradigm, ATP levels had recovered to $66 \pm 3 \%$ of control.

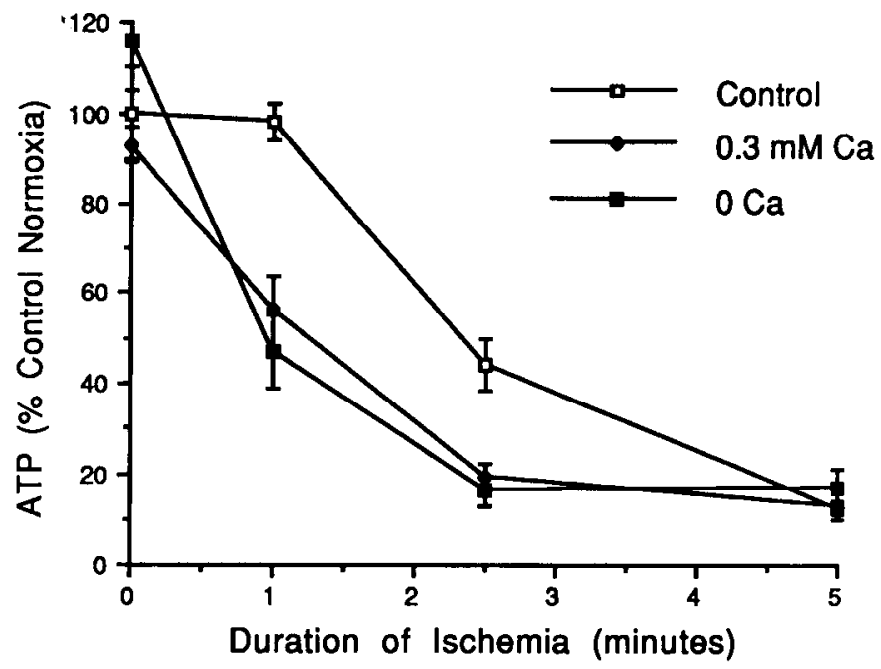

Figure 5. Effects of $0.3 \mathrm{~mm} \mathrm{Ca}$ and $0 \mathrm{Ca}$ on ATP levels in the CAl region of the rat hippocampal slice during ischemia. For $0.3 \mathrm{mM} \mathrm{Ca}$, slices were exposed to $0.3 \mathrm{~mm} \mathrm{Ca}$ for $45 \mathrm{~min}$ prior to and during ischemia. For $0 \mathrm{Ca}$, slices were exposed to $0 \mathrm{Ca}$ buffer for $20 \mathrm{~min}$ prior to the ischemic period and also during ischemia. ATP levels are expressed as percentage of levels in standard buffer prior to ischemia (Control normoxia). ATP in control normoxia slices $=5.2 \pm 0.5 \mathrm{nmol} /$ mg dry wt; $n=13-26$ for control, $7-12$ for $0.3 \mathrm{~mm} \mathrm{Ca}, 8-12$ for $0 \mathrm{Ca}$. Values for $0 \mathrm{Ca}$ and $0.3 \mathrm{~mm} \mathrm{Ca}$ at 1 and $2.5 \mathrm{~min}$ of ischemia are significantly different from control ischemia, $p<0.01$. 

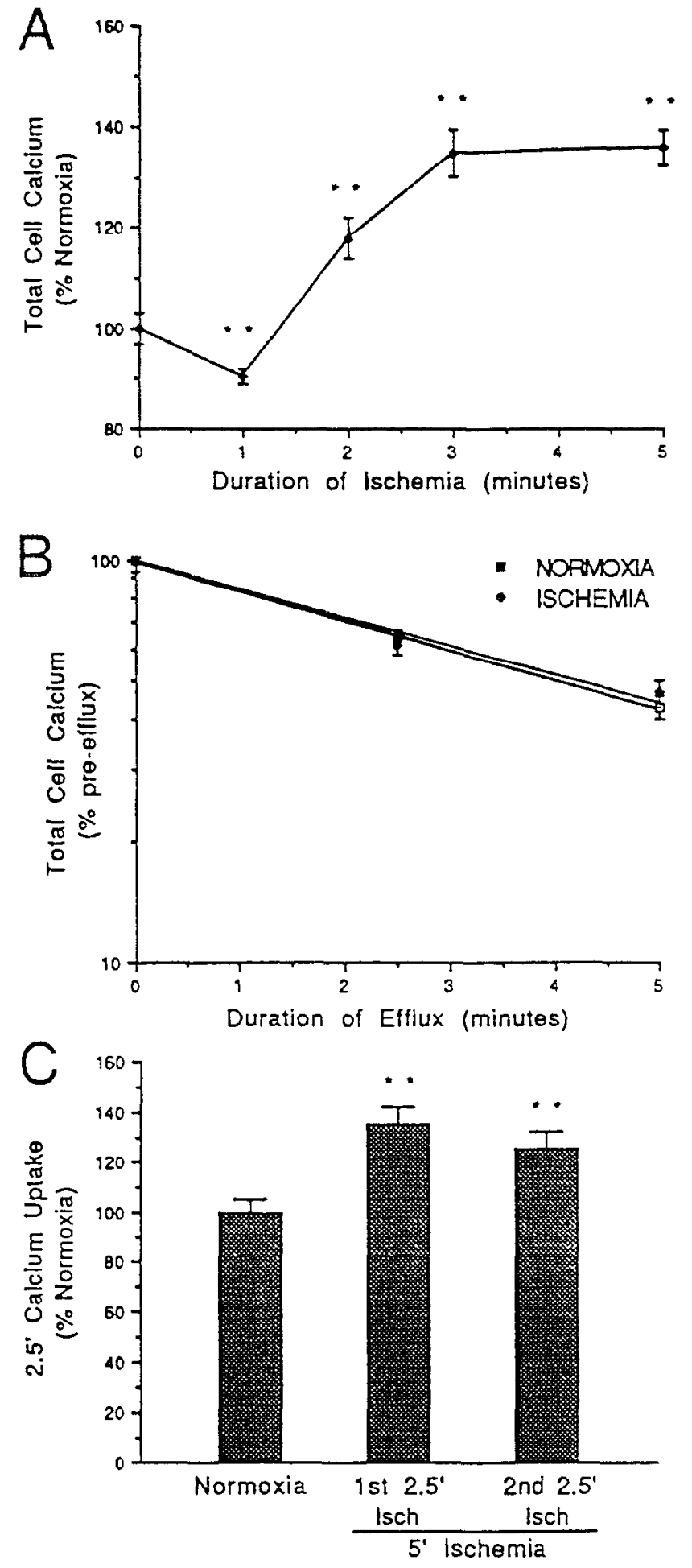

Figure 6. Total calcium accumulation and unidirectional fluxes during in vitro ischemia $A$, Total cell calcium. Cell calcium content is expressed as percentage of levels in standard buffer prior to ischemia (control normoxia). Calcium in control normoxia $=9.0 \pm 0.6 \mathrm{nmol} / \mathrm{mg} \mathrm{dry} \mathrm{wt}$. In each experiment the slices were exposed to ${ }^{45} \mathrm{Ca}$ for a total of $50 \mathrm{~min}$; the last $0-5 \mathrm{~min}$ were ischemic. $n=20-51$ for different time points. Ischemia values are significantly different from normoxia for all time points $(p<0.01) . B$, Ca efflux. Slices were loaded with ${ }^{45} \mathrm{Ca}$ for $50 \mathrm{~min}$ and then placed in $0 \mathrm{Ca} / 2 \mathrm{~mm}$ EGTA buffer for $2 \mathrm{~min}$ to remove extracellular ${ }^{45} \mathrm{Ca}$. Slices were then exposed to $0 \mathrm{Ca} / 2 \mathrm{~mm}$ EGTA in either normoxic or ischemic buffer for the time shown on the abscissa, and then analyzed for ${ }^{45} \mathrm{Ca}$. Cell calcium prior to efflux $=7.1 \pm 0.3$ $\mathrm{nmol} / \mathrm{mg}$ dry wt. $n=20$ for all points. There is no significant difference

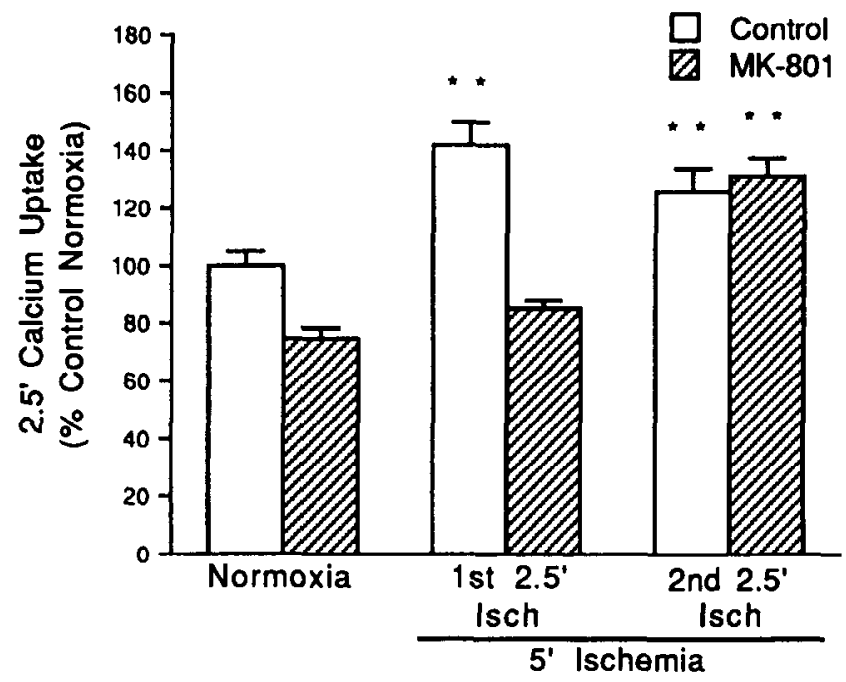

Figure 7. Effect of MK-801 on ${ }^{45} \mathrm{Ca}$ uptake during ischemia. Slices were exposed to ${ }^{45} \mathrm{Ca}$ for $2.5 \mathrm{~min}$ in normoxia, at the onset of ischemia (1st 2.5'), or after $2.5 \mathrm{~min}$ of ischemia ( $\left.2 n d 2.5^{\prime}\right)$. The NMDA antagonist MK-801 blocked the increased calcium influx during the first $2.5 \mathrm{~min}$ of ischemia, but did not block the increase during the second $2.5 \mathrm{~min}$ of ischemia. The drug reduced uptake in normoxia. Uptake in control normoxia, $4.3 \pm 0.2 \mathrm{nmol} / \mathrm{mg} \mathrm{dry} \mathrm{wt} / 2.5 \mathrm{~min} ; n=18$. **, Significantly different from normoxia for the same treatment (control or drug), $p<$ 0.01 .

Kinetics of calcium changes during 5 min of in vitro ischemia

The importance of cell $\mathrm{Ca}$ in transmission damage led to an investigation of the mechanisms by which this parameter increased during in vitro ischemia.

There was a $10 \%$ decrease in total cell $\mathrm{Ca}$ after $1 \mathrm{~min}$ of ischemia, followed by a rapid increase over the next $2 \mathrm{~min}$. Elevated levels of cell $\mathrm{Ca}$ were then maintained for the duration of the $5 \mathrm{~min}$ ischemic period (Fig. 6A). The early decrease is probably due to release of $\mathrm{Ca}$ from intracellular stores into the cytosol, with subsequent stimulation of $\mathrm{Ca}$ efflux processes.

Unidirectional calcium fluxes during $5 \mathrm{~min}$ of in vitro ischemia

The increase in cell $\mathrm{Ca}$ could result from increased $\mathrm{Ca}$ influx, decreased Ca efflux, or a combination of both. Figure $6 B$ shows that ischemia had no effect on ${ }^{45} \mathrm{Ca}$ efflux into a Ca-free EGTAfortified buffer. The rate constant in both cases was $0.17 \mathrm{~min}^{-1}$. Figure $6 C$ shows that ischemia increased the influx of ${ }^{45} \mathrm{Ca}$ during both the first and second halves of the $5 \mathrm{~min}$ of ischemia. The increases were similar during the two periods and were both similar to the net uptake occurring during the ischemia (about $35 \%)$.

These results strongly suggest that the $\mathrm{Ca}$ accumulation during in vitro ischemia can be accounted for by an activation of influx processes. The nature of these processes was investigated.

\section{Effects of MK-801 on Ca influx}

As shown in Figure 7, $10 \mu \mathrm{M}$ MK-801, a noncompetitive NMDA reccptor antagonist (Wong ct al., 1988), rcduccd normoxic influx

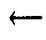

between the efflux rate constant during normoxia and ischemia; $k=$ $0.17 \mathrm{~min}^{-1}$ for both conditions. $C, \mathrm{Ca}$ influx. Slices were exposed to ${ }^{45} \mathrm{Ca}$ for $2.5 \mathrm{~min}$ either during normoxia or during the first or second periods of in vitro ischemia. $n=18$. ${ }^{* *}$, Significantly different from normoxia, $p<0.01$. 

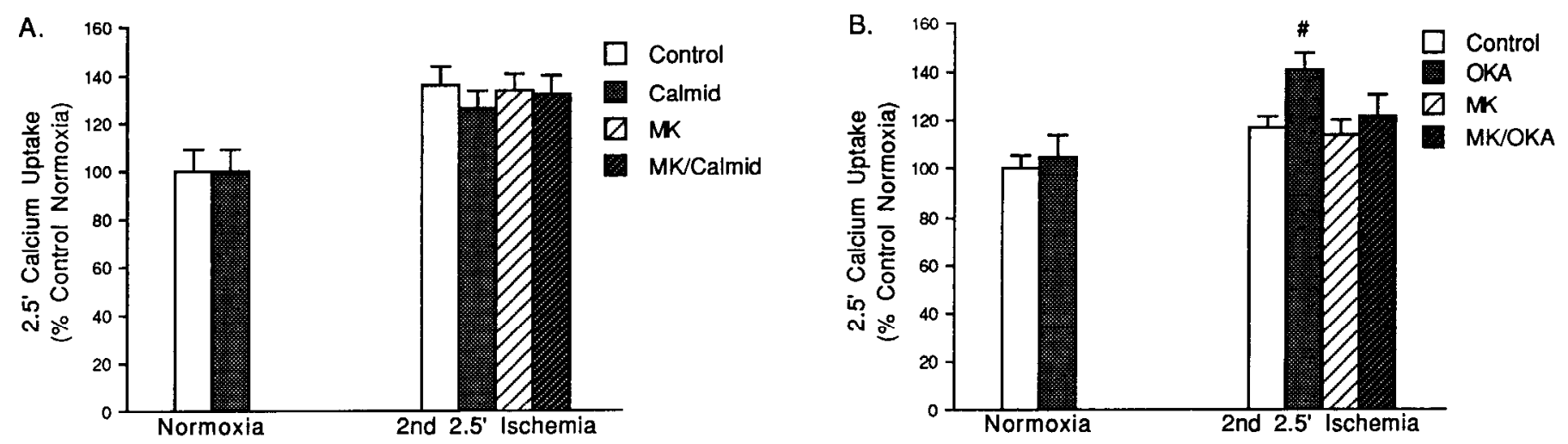

Figure 8. Effects of calmidazolium and okadaic acid on ${ }^{45} \mathrm{Ca}$ uptake during the second $2.5 \mathrm{~min}$ of ischemia. Slices were treated as described for Figure 7. $A$, Calmidazolium at $5 \mu \mathrm{M}$ did not affect normoxic or ischemic calcium uptake. $B$, Okadaic acid at $0.5 \mu \mathrm{M}$ increased calcium uptake during the second 2.5 min of ischemia; this increase was blocked by MK-801. $n=12$. Calmid, $5 \mu \mathrm{M}$ calmidazolium; $M K$, MK-801; OKA, $0.5 \mu \mathrm{M}$ okadaic acid. \#, Significantly different from control ischemia, $p<0.05$, by ANOVA and Fisher's least significant difference test.

by approximately $25 \%$, indicating that a component of resting Ca influx is via NMDA channels. This reduction cannot be a result of decreased diffusion through the intercellular spaces, as an identical lowering of total cell Ca occurred (data not shown). MK-801 also completely blocked the increased influx during the first $2.5 \mathrm{~min}$ but had no effect on the influx during the second $2.5 \mathrm{~min}$ of ischemia. Thus, early Ca entry appears to rely completely on flux through NMDA receptor-linked channels. However, this mechanism appears to inactivate after a short period of ischemia, as it makes no contribution to influx during the second $2.5 \mathrm{~min}$ period. The absence of any NMDA-mediated $\mathrm{Ca}$ influx during this late period shows that even the NMDA receptor-mediated influx occurring in normoxic conditions is blocked.

\section{Inactivation of NMDA-mediated calcium influx}

The apparent elimination of Ca flux through the NMDA channel during the second $2.5 \mathrm{~min}$ of ischemia may have resulted from dephosphorylation of the receptor-channel complex (MacDonald et al., 1989) following the rapid fall in ATP levels. This was tested using inhibitors of protein phosphatases. Calmidazolium, which blocks calcium/calmodulin activation of calcineurin (Gietzen et al., 1981), did not affect $\mathrm{Ca}$ influx during the second $2.5 \mathrm{~min}$ of ischemia (Fig. 8A). However, okadaic acid, which blocks the constitutively active phosphatases 1 and 2a (Cohen et al., 1990), enhanced influx during the second $2.5 \mathrm{~min}$ of ischemia. Furthermore this enhancement was completely abolished by MK-801 (Fig. 8B). This indicates that dephosphorylation of NMDA-sensitive channels accounts for the abolition of $\mathrm{Ca}$ entry through these channels during the in vitro ischemia.

Components of late calcium influx

The change of influx during the second $2.5 \mathrm{~min}$ of ischemia, as compared with control conditions, included the elimination of the normoxic NMDA-mediated $\mathrm{Ca}$ influx as well as any new fluxes caused by ischemia. In order to isolate the latter, $10 \mu \mathrm{M}$ MK-801 was included in the buffer throughout these experiments.

Figure 9 shows that the AMPA/kainate receptor antagonist DNQX $(100 \mu \mathrm{M})$ did not block ischemia-induced influx, nor did the $\alpha 1$-antagonist prazosin at a concentration of $10 \mu \mathrm{M}$ (data not shown).

The voltage-dependent $\mathrm{Ca}$ channel antagonist nifedipine (50 $\mu \mathrm{M})$ reduced the $\mathrm{Ca}$ influx by $25 \%$, and benzamil $(100 \mu \mathrm{M})$, an inhibitor of the $\mathrm{Na} / \mathrm{Ca}$ exchange carrier, blocked an additional $35 \%$ (Fig. 10). Benzamil was added in the presence of nifedipine to ensure that its effect was not due to blockade of L-type voltage-dependent calcium channels (Kleyman and Cragoe, 1988). Approximately $40 \%$ of the late ischemic increase was unaffected by these inhibitors.

The inhibitory effect of benzamil did not differentiate between whether in vitro ischemia activated the $\mathrm{Ca} / \mathrm{Na}$ exchange or $\mathrm{Ca} /$ $\mathrm{Ca}$ exchange mode of the $\mathrm{Na} / \mathrm{Ca}$ exchanger. Figure 11 shows results of a study designed to help resolve this. Figure $11 \mathrm{~A}$ shows that, during normoxia, $100 \mu \mathrm{M}$ benzamil completely blocked additional Ca influx caused by removal of sodium but had no effect on basal $\mathrm{Ca}$ influx. This indicates, first, that in the resting state the $\mathrm{Ca}$ influx via the $\mathrm{Na} / \mathrm{Ca}$ exchanger is negligible. Second, it demonstrates that $100 \mu \mathrm{M}$ benzamil does completely block $\mathrm{Ca}$ influx via the exchanger, when the latter is active. Figure $11 B$ shows that the normal increase in $\mathrm{Ca}$ influx during the second $2.5 \mathrm{~min}$ of ischemia was reduced approximately $40 \%$ when $\mathrm{NaCl}$ was removed from the bathing medium during the experiment (compare the difference between the dark bars with the difference between the light bars). The size of the reduction

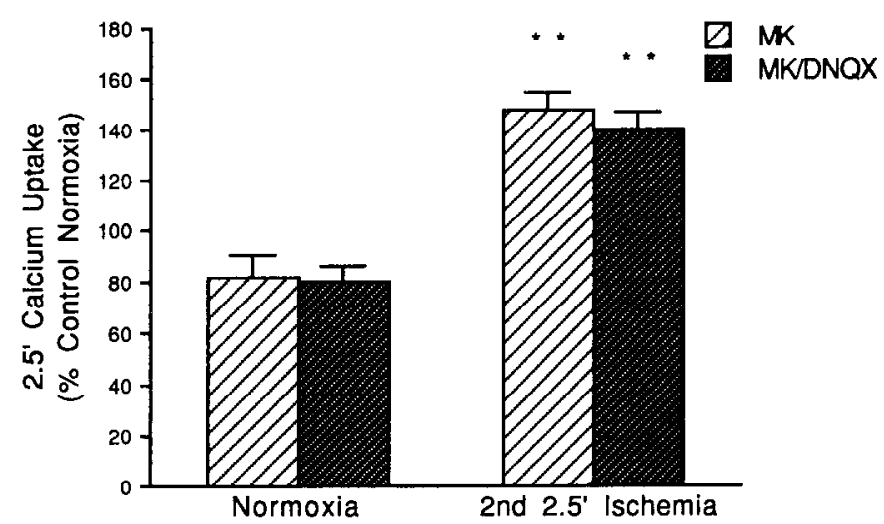

Figure 9. Effects of an AMPA/kainate receptor antagonist on ${ }^{45} \mathrm{Ca}$ uptake during the second $2.5 \mathrm{~min}$ of ischemia. Slices were treated as for Figure 7. DNQX was tested in the presence of $10 \mu \mathrm{M}$ MK-801 $(M K)$. DNQX at $100 \mu \mathrm{M}$ did not affect calcium uptake during the second 2.5 min of ischemia. $n=12$ for DNQX experiments. ${ }^{* *}$, Significantly different from normoxia for the same treatment, $p<0.01$. 


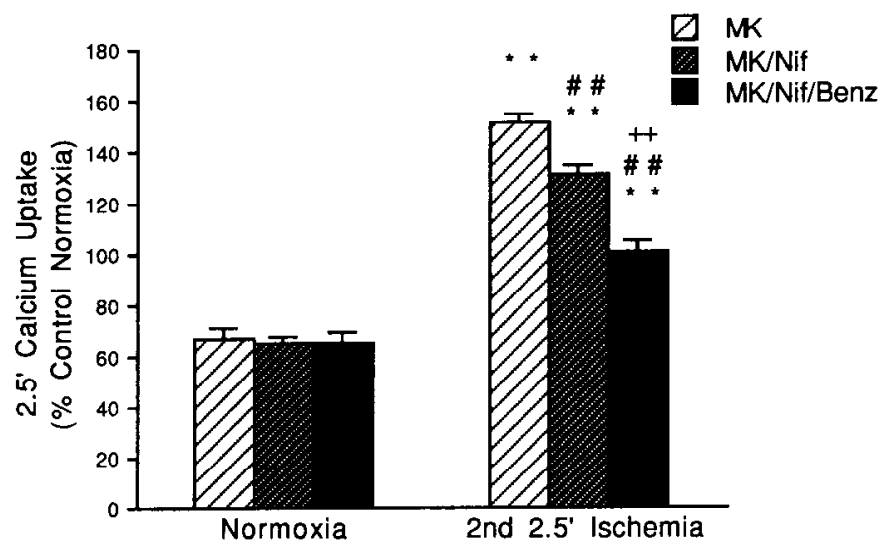

Figure 10. Effects of nifedipine and benzamil on ${ }^{45} \mathrm{Ca}$ uptake during the second $2.5 \mathrm{~min}$ of ischemia. Slices were treated as for Figure 7. Antagonists were tested in the presence of MK-801 (MK). Nif, $50 \mu \mathrm{M}$ nifedipine; Benz, $100 \mu \mathrm{M}$ benzamil. $n=12 .{ }^{* *}$, Significantly different from normoxia for the same treatment, $p<0.01$; \#\#, significantly different from $M K$ ischemia, $p<0.01 ;++$, significantly different from $M K / N i f$ ischemia, $p<0.01$. Significance tested by ANOVA and Fisher's least significant difference test.

was very similar to the size of the reduction caused by benzamil during ischemia in normal buffer (Fig. 10). This similarity suggests that the ischemic $\mathrm{Ca}$ influx blocked by benzamil is due to $\mathrm{Na}$ entry and resultant $\mathrm{Na} / \mathrm{Ca}$ exchange flux, and hence represents a net Ca entry.

\section{Relationship of calcium movements to ischemic transmission damage}

Five minutes of ischemia caused complete LTF (Fig. 12, CONT). Neither NMDA antagonists (MK-801, CGS-19755) nor nifedipine provided significant protection against damage in spite of their effects on $\mathrm{Ca}$ fluxes, nor was protection provided by the combination of MK-801, nifedipine, and benzamil. Thus, combined blockade of the early $\mathrm{Ca}$ entry and most of the later $\mathrm{Ca}$ entry did not prevent the damage when the slices were incubated in $2.4 \mathrm{~mm}$ Ca-containing buffer.

In contrast, combined blockade of NMDA-mediated channels and non-NMDA glutamate receptors provided strong protection against LTF (Fig. 12). Either DNQX/glycine, which blocks AMPA/kainate receptors, or DTG, which blocks ischemic glutamate accumulation in the extracellular medium and in this way appears to block activation of AMPA/kainate receptors (Lobner and Lipton, 1990), provided strong protection against LTF, when combined with MK-801. Ketamine (1 mM), which blocks both glutamate accumulation (Lobner and Lipton, 1990) and NMDA channels, protected against LTF, as did $10 \mathrm{~mm}$ kynurenic acid, which blocks both the ionotropic glutamate receptor classes (Ganong et al., 1983).

In contrast to its effect in buffer containing $2.4 \mathrm{~mm} \mathrm{Ca}, \mathrm{MK}-$ 801 strongly protected against LTF when extracellular Ca was at a more physiological level, $1.2 \mathrm{~mm}$. (Fig. 13).

\section{Discussion}

\section{Methodological considerations}

Possible effects of extracellular space changes on ${ }^{45} \mathrm{Ca}$ measurements. It is important to assess any artifactual effects of extracellular space changes on the measured ischemic uptake of ${ }^{45} \mathrm{Ca}$. Cell swelling rapidly decreases the extracellular space during anoxia/ischemia (Harrevald and Ochs, 1956; Boer et al., 1990). This decreases volume fraction and increases tortuosity of the intercellular spaces and so should slow diffusion of $\mathrm{Ca}$ into the slice (Nicholson, 1988-89). The magnitude of the effect is hard to predict, but it will clearly reduce the measured Ca uptake. It is improbable that the increased tortuosity will remain during the ice-cold $\mathrm{LaCl}_{3}$ washout, as both sets of slices are in aerated ice-cold buffer for $60 \mathrm{~min}$. If it does it should not affect efflux from the extracellular space during this washout as the halftime for removal from that space is $4 \mathrm{~min}$ (Kass and Lipton, 1986) compared with the $60 \mathrm{~min}$ during which slices are washed. Thus, the net effect of the cell volume changes should be, if anything, to cause an underestimate of the change in unidirectional influx.
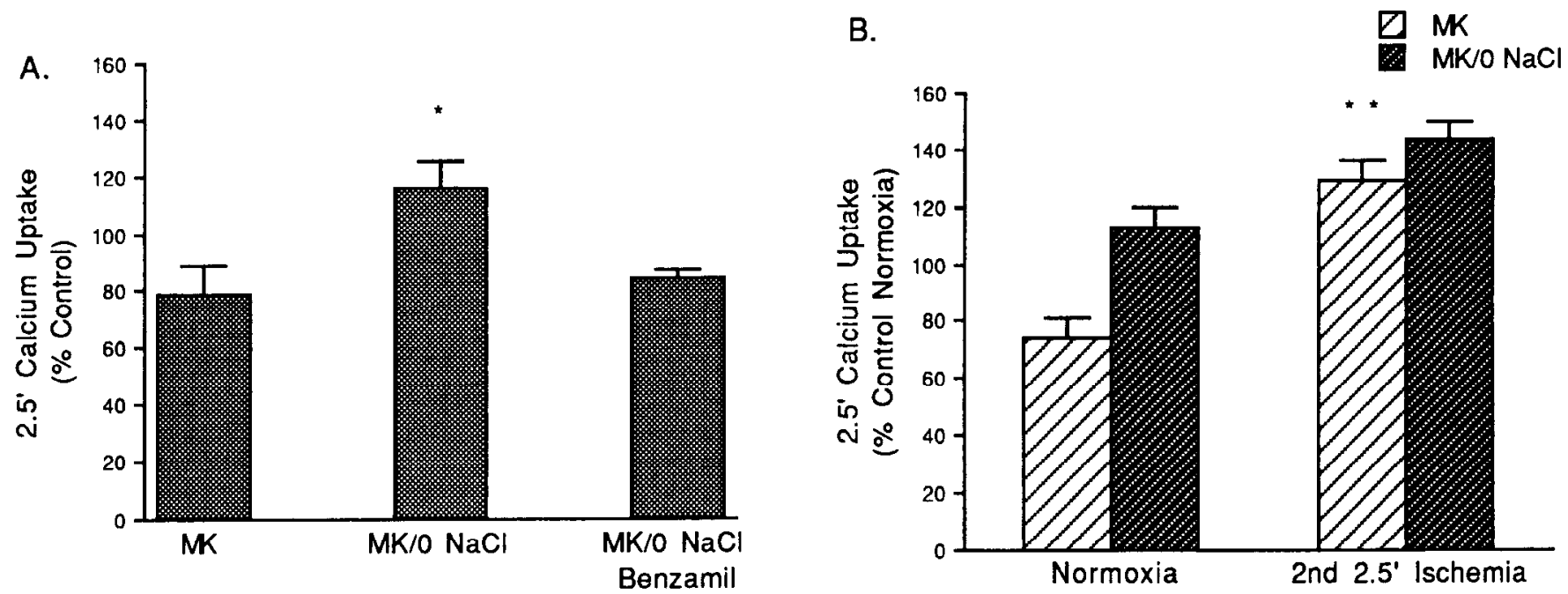

Figure 11. Nature of benzamil-inhibitable Ca influx. Slices were treated as for Figure 7. Experiments were performed in the presence of MK-801. $\mathrm{NaCl}$ in the bathing medium was replaced with choline-Cl $10 \mathrm{~min}$ prior to and during the $2.5 \mathrm{~min}{ }^{45} \mathrm{Ca}$ uptake period. $A$, Benzamil blockade of $\mathrm{Ca}$ influx in low-Na buffer. The reduced-Na buffer significantly stimulated calcium uptake $\left({ }^{*}, p<0.05\right)$ and this increase was blocked by $100 \mu \mathrm{M}$ benzamil. $n=8-16$. B , Effects of low-Na buffer on ${ }^{45} \mathrm{Ca}$ uptake during the second $2.5 \mathrm{~min}$ of ischemia. The rise in ${ }^{45} \mathrm{Ca}$ uptake during ischemia was reduced in low-Na buffer. $n=16{ }^{*}$, significantly different from normoxia for the same treatment, $p<0.01$. 
Figure 12. Effect of antagonists on recovery of the population spike after 5 min of ischemia. Recovery is defined $60 \mathrm{~min}$ after $5 \mathrm{~min}$ of ischemia as a percentage of the amplitude prior to the addition of any drug. CONT, no drug; $M K, 10 \mu \mathrm{M}$ MK-801; $C G, 100 \mu \mathrm{M}$ CGS$19755 ; N F, 50 \mu \mathrm{M}$ nifedipine; $B Z, 100$ $\mu \mathrm{M}$ benzamil; $D G, 25 \mu \mathrm{M}$ DTG; $D X, 100$ $\mu \mathrm{M}$ DNQX; $G Y, 100 \mu \mathrm{M}$ glycine; $K T, 1$ mM ketamine; $K Y N, 10 \mathrm{~mm}$ kynurenic acid. ${ }^{* *}$, significant protection, $p<0.01$. Some of the results have been published previously (Lobner and Lipton, 1990) but are included for clarity. as the amplitude of the population spike

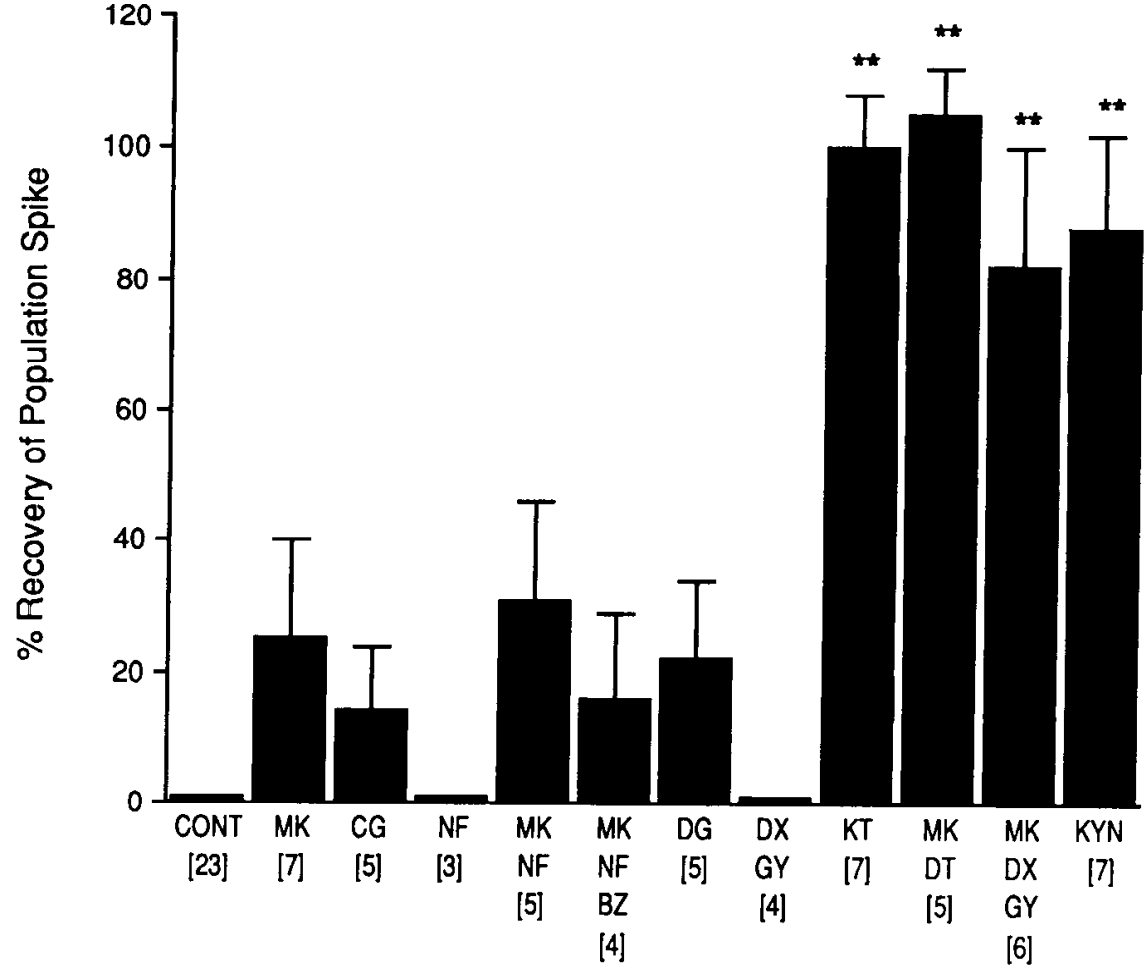

Localizations of ${ }^{45} \mathrm{Ca}$. Implicit in the interpretation of the results is that the measured calcium changes reflect changes in neuronal compartments that are undergoing damage. These include either or both of the two components of the electrophysiological pathway, the terminals of the Schaffer collaterals, and the dendrites/cell somata of the pyramidal cells.

About $10 \%$ of the microdissected region comprised the pyramidal cell layer, which is approximately $90 \%$ pyramidal cell somata and dendrites (Sloviter, 1989). There is very little glial tissue, especially in the slice (Feig and Lipton, 1990).

The great majority of the tissue in stratum radiatum comprised dendritic profiles and presynaptic axons and boutons: dendrites (including spines), $47 \pm 4 \%$; presynaptic fibers and

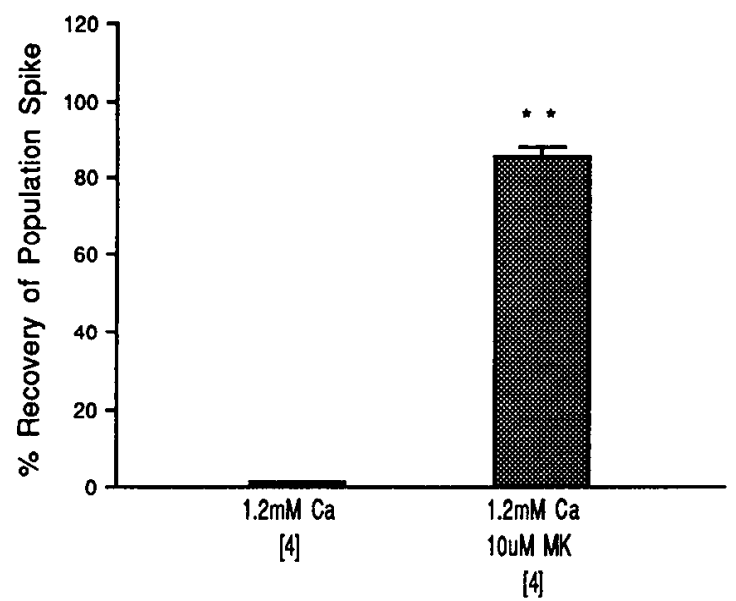

Figure 13. Effects of MK-801 on recovery of the population spike in $1.2 \mathrm{~mm}$ Ca buffer. The standard buffer was changed to $1.2 \mathrm{~mm} \mathrm{Ca}$ buffer $45 \mathrm{~min}$ prior to ischemia and during ischemia. Standard buffer was reinstated for the recovery period. ${ }^{* *}$, significant protection, $p<0.01$. boutons, $31 \pm 3 \%$; cross-sectional profiles of either small axons or dendrites, $9 \pm 2 \%$; other (including glial profiles and unidentified fragments), $14 \pm 3 \%$. Glial cell bodies occupy less than $1 \%$ of the region $(0.09 \pm 0.03 \%)$ The extracellular space was $10 \pm 5 \%$ of the tissue (see Materials and Methods). Although their origin is not precisely known, the great majority of the dendrites are part of CAl pyramidal cells (Schlander and Frotscher, 1986; Feig and Lipton, 1993), and the presynaptic elements should be almost completely associated with Schaffer collateral or commissural fibers, as these make up the overwhelming preponderance of fibers in this region (Ishizuka et al., 1990). Thus, tissue in stratum radiatum is largely associated with elements that were studied electrophysiologically.

Stratum lacunosum-moleculare comprised approximately $20 \%$ of the dissected region. It includes distal dendrites from the CAI pyramidal cells but is largely made up of terminals and interneurons that were not studied electrophysiologically. It was included because the stratum lacunosum-moleculare/stratum radiatum border is difficult to identify with certainty in lyophilized tissue.

The above analysis shows that approximately $65 \%$ of the tissue in the microdissected sample is composed of cellular elements that were studied electrophysiologically. This includes ascribing $10 \%$ of dendrites and presynaptic elements in stratum radiatum to cells that were not part of the electrophysiological pathway being studied. Thus, the precise extent to which the measured cell Ca represents changes in tissue that was damaged cannot be calculated. Howcver, the potentially damaged elements do represent about two-thirds of the analyzed tissue, so unless they are far less sensitive to the manipulations in these studies than are other tissue elements, the measured changes should largely reflect changes in them. In the analysis of the data it is assumed that the measured percentage changes in $\mathrm{Ca}$, and ATP, do represent percentage changes in damaged elements. 


\section{Calcium and long-term transmission failure}

A principle aim of this study was to determine whether there is a positive relationship between cell $\mathrm{Ca}$ levels during ischemia, and the extent of ischemic damage. Such a relationship must be true over some range if cell $\mathrm{Ca}$ is a cause of damage.

Intracellular $\mathrm{Ca}$ was varied in two different ways and in both cases there was a positive monotonic relation between the average amount of $\mathrm{Ca}$ within the cells and damage. For this $5 \mathrm{~min}$ in vitro exposure, transmission damage was complete when mean $\mathrm{Ca}$ levels during the in vitro ischemia were somewhat less than those in resting cells at $2.4 \mathrm{mMCa}{ }_{v}$ (Fig. 2). At the other extreme, there was zero damage when cell $\mathrm{Ca}$ was $20 \%$ of the resting value.

The relationship between damage and $\mathrm{Ca}$ cannot be explained by $\mathrm{Ca}$ accelerating the fall in ATP levels. The rate at which ATP declines during ischemia was actually accelerated in the $0 \mathrm{Ca}$ conditions (Fig. 5). This result, coupled with previous results on precisely the same system, which showed that glutamate release during in vitro ischemia is not affected by $20 \mathrm{~min}$ of 0 $\mathrm{Ca}$ incubation (Lobner and Lipton, 1990), establish quite firmly that a parameter related to total cell $\mathrm{Ca}$ acts directly to initiate, or help initiate, ischemic damage to synaptic transmission. This parameter may well be cytosolic $\mathrm{Ca}$, which should reflect total cell $\mathrm{Ca}$ as a result of reequilibration of energy-dependent stores across organelle membranes during ischemia (Siesjo, 1988). While the precise quantitative relationship between total cell $\mathrm{Ca}$ and cytosolic $\mathrm{Ca}$ during ischemia is not known, the fact that organelle accumulation is energy dependent and cytosolic (Ca) dependent (Siesjo and Bengtsson, 1989; Gunter and Pfeifer, 1990) implies that cytosolic levels during ischemia will increase with both the decreased rate of oxygen utilization and the amount of $\mathrm{Ca}$ in organelles and extracellular medium.

The results in $0 \mathrm{Ca}$ buffer demonstrated that some cell damage occurred without any increase in total cell $\mathrm{Ca}$; however, in normal extracellular media there is a net $\mathrm{Ca}$ influx during in vitro ischemia and this will contribute to damage by elevating total cell $\mathrm{Ca}$.

\section{Calcium efflux during ischemia}

There was no measured change in the ${ }^{45} \mathrm{Ca}$ efflux during $5 \mathrm{~min}$ of ischemia. Earlier studies had shown a decrease in Ca efflux that was ascribed to inhibition of the Ca-ATPase (Lipton and Lobner, 1990). However, it appears that the reported decrease was an artifact of the experimental procedure, in which ${ }^{45} \mathrm{Ca}$ efflux was measured into a $0 \mathrm{Ca}$-containing buffer without EGTA. There is significant backflux of $\mathrm{Ca}$ from the extracellular space in that situation, illustrated by the much slower efflux rate constant when EGTA was excluded $\left[0.11 \mathrm{~min}^{-1}\right.$ without EGTA (Lipton and Lobner, 1990) vs. $0.17 \mathrm{~min}^{-1}$ with EGTA in this study]. The increased influx that occurs during in vitro ischemia enhances the backflux, and thus leads to an apparent reduction in the efflux rate constant during ischemia when the $\mathrm{Ca}$ is not chclatcd by EGTA. The absence of a change in cfflux docs not necessarily imply that processes contributing to $\mathrm{Ca}$ efflux are unaltered by in vitro ischemia. It is quite possible that efflux mechanisms at the plasmalemma are inhibited due to low ATP and elevated intracellular $\mathrm{Na}$ (DiPolo and Beauge, 1988; Siesjo and Bengtsson, 1989), but that increases in cytosolic Ca due to efflux from organelles maintain plasmalemma efflux rates by increasing the substrate concentrations for these mechanisms.

The lack of any change in efflux led to the conclusion that the basis for the increased Ca uptake during ischemia was an increased unidirectional influx.

\section{NMDA receptor-mediated influx, and its desensitization}

The increase in $\mathrm{Ca}$ influx during the first $2.5 \mathrm{~min}$ of ischemia was completely blocked by $10 \mu \mathrm{M}$ MK-801, the noncompetitive NMDA antagonist. It is thus probable that the calcium enters through the NMDA-mediated channels, although it is possible that flux through the NMDA channels leads to some $\mathrm{Ca}$ flux through other channels. The NMDA-mediated Ca entry is consistent with the rapid release of glutamate during ischemia in this system (Lobner and Lipton, 1990), the early depolarization of the postsynaptic cells (Rader and Lanthorn, 1989), and the well-established Ca conductance of the NMDA-sensitive channels (Dingledine, 1983). There is similar evidence that the early ischemia-induced $\mathrm{Ca}$ influx in intact brain is via NMDA channels (Benveniste et al., 1988; Silver and Erecinska, 1990).

In contrast to the first $2.5 \mathrm{~min}$, NMDA antagonists did not affect $\mathrm{Ca}$ influx during the second $2.5 \mathrm{~min}$ of ischemia, indicating there was no flux through NMDA-sensitive channels. Conditions during this period would favor entry through NMDA channels because the pyramidal cells are clearly depolarized (Rader and Lanthorn, 1989). Thus, the channels must desensitize. The effects of okadaic acid strongly suggest that this results from a dephosphorylation process. The phosphatase 1 and 2a inhibitor enhanced $\mathrm{Ca}$ influx during this period and the enhancement was completely blocked by $10 \mu \mathrm{M} \mathrm{MK-801}$. Thus, there is NMDAsensitive influx during the second $2.5 \mathrm{~min}$ of ischemia if dephosphorylation is prevented. The net dephosphorylation probably results from the fall in ATP during ischemia (MacDonald et al., 1989). The inactivation of the NMDA channel certainly reduces $\mathrm{Ca}$ entry during ischemia, and so tends to protect against ischemic damage.

\section{Non-NMDA receptor-mediated influx}

About $25 \%$ of the increased influx during the second $2.5 \mathrm{~min}$ of ischemia was blocked by $50 \mu \mathrm{M}$ nifedipine, a concentration well above the $K_{i}$ for this voltage-dependent calcium channel blocker (Godfraind et al., 1986). This might well represent Ca entry through L-type channels, which appear to be clustered at proximal dendrites and somatic regions of the CA1 pyramidal cells (Westenbroek et al., 1990), and which are blocked by 5$10 \mu \mathrm{M}$ nifedipine in hippocampal slices (O'Dell and Alger, 1991); there is very little nifedipine-sensitive influx of $\mathrm{Ca}$ into presynaptic terminals (Carvalho et al., 1986; Suszkiw et al., 1989). Other voltage-dependent $\mathrm{Ca}$ and $\mathrm{Na}$ channels may also be involved (Pauwels et al., 1990; Richard et al., 1991). Although nifedipine has other, nonchannel, effects at these concentrations, they should not account for the reduced accumulation. The bestestablished of these effects are inhibition of the Ca-ATPase (Hata et al., 1988) and inhibition of mitochondrial $\mathrm{Na} / \mathrm{Ca}$ exchange (Vaghy et al., 1982), both of which would increase Ca accumulation. It has becn suggestcd that nifedipine partially blocks plasmalemma $\mathrm{Na} / \mathrm{Ca}$ exchange (Carvalho et al., 1986), which could account for the inhibition of influx, but in well-controlled studies on heart sarcolemma the drug does not affect this process (Hata et al., 1988). Thus, it seems quite probable that a portion of the $\mathrm{Ca}$ uptake is through voltage-dependent $\mathrm{Ca}$ channels. Nimodipine blocks part of the increase in cytosolic Ca during focal ischemia, indicating there is a similar pathway in situ (Uematsu et al., 1991). 


\section{Relationship of calcium fluxes to ischemic damage}

The extent of LTF was dependent on tissue Ca levels and was maximal in buffer containing $1.2 \mathrm{~mm} \mathrm{Ca} \mathrm{(Fig.} \mathrm{3).} \mathrm{Tissue} \mathrm{calcium}$ levels at the end of the $5 \mathrm{~min}$ ischemic period in this buffer were identical to those in $2.4 \mathrm{~mm}$ Ca buffer prior to the ischemia. Thus, it is not surprising that blocking the ischemic influx in $2.4 \mathrm{~mm}$ Ca buffer with a variety of agents failed to protect against damage: the total cell calcium that was present prior to ischemia should have been adequate to cause complete damage. In contrast to this situation, blockade of NMDA-mediated Ca influx by MK-801 did strongly attenuate LTF when slices were in 1.2 mм Ca buffer. In this case, where normal resting cell Ca levels are below those required to cause complete LTF, reducing resting influx and preventing the early influx of $\mathrm{Ca}$ with $\mathrm{MK}-801$ was protective. The increased influx during the second $2.5 \mathrm{~min}$ was apparently not adequate to cause measurable damage during this short ischemic exposure.

The ability of NMDA antagonists to protect against ischemic damage varies widely in different systems (Simon et al., 1984; Weiss et al., 1986; Clark and Rothman, 1987; Kochhar et al., 1988; Fleischer et al., 1989; Kass et al., 1989; Bullock et al., 1990; Buchan et al., 1991). In the severe ischemic conditions of the present experiments no protection was provided at 2.4 mm extracellular Ca. At $1.2 \mathrm{~mm}$ extracellular Ca there was good protection. These varied results can all be explained by the observations that total cell $\mathrm{Ca}$ is a determinant of cell damage during ischemia and that NMDA antagonists prevent only one component of Ca entry. Whether or not NMDA antagonists are protective in a given instance will thus depend on whether cell Ca levels rise to damaging levels in the absence of activation of NMDA receptors. That, in turn, will depend on severity of the depletion of cell energy levels and the duration of the insult, as well as the presence of other transmitters, which may also increase cytosolic $\mathrm{Ca}$.

Combining an NMDA antagonist with agents that block activation of AMPA/kainate receptors was able to prevent LTF, even at $2.4 \mathrm{~mm}$ extracellular $\mathrm{Ca}$. This was seen with the competitive antagonists DNQX and kynurenic acid and also with agents that block glutamate accumulation during ischemia (DTG or high levels of ketamine; Lobner and Lipton, 1990). Activation of AMPA/kainate receptors thus appears able to cause cell damage, but not via activation of $\mathrm{Ca}$ influx during in vitro ischemia; DNQX had no effect on ischemic $\mathrm{Ca}$ influx. It is possible that DNQX, which is only slowly washed out of the tissue, attenuated $\mathrm{Ca}$ influx following the return to normoxic conditions and so protected by actions during the postischemic period, as appears to occur in situ (Sheardown et al., 1990). It is also possible that AMPA/kainate binding may enhance $\mathrm{Na}$ entry, which would in turn increase efflux of $\mathrm{Ca}$ from the mitochondria (Nicholls and Scott, 1980) and so increase cytosolic Ca. Alternatively, the AMPA/kainate receptors may enhance damage by a Ca-independent mechanism (Dykens et al., 1987).

\section{References}

Albaum HG, Werner KN, Chinn HI (1953) Chemical changes in rabbit brain during anoxia. Am J Physiol 174:408-412.

Amagasa M, Ogawa A, Yoshimoto T (1990) Effects of calcium and calcium antagonists against deprivation of glucose and oxygen in guinea pig hippocampal slices. Brain Res 526:1-7.

Arai A, Kessler M, Lee K, Lynch G (1990) Calpain inhibitor improves the recovery of synaptic transmission from hypoxia in hippocampal slices. Brain Res 532:63-68.
Benveniste H, Drejer J, Schousboe A, Diemer N (1984) Elevation of the extracellular concentrations of glutamate and aspartate in rat hippocampus during transient cerebral ischemia monitored by intracerebral microdialysis. J Neurochem 43:1369-1374.

Benveniste H, Jorgensen MB, Diemer NH, Hansen AJ (1988) Calcium accumulation by glutamate receptor activation is involved in hippocampal cell damage after ischemia. Acta Neurol Scand 78:529536.

Boer J, Klein AC, Postema F, Go KG, Korf J (1990) Rat striatal cation shifts reflecting hypoxic-ischemic damage can be predicted by on-line impedance measurements. Stroke 20:1377-1382.

Buchan A, Li H, Pulsinelli WA (1991) The $N$-methyl-D-aspartate antagonist MK-801 fails to protect against neuronal damage caused by transient, severe, forebrain ischemia. J Neurosci 11:1049-1056.

Bullock R, Graham DI, Chen MH, Lowe D, McCulloch J (1990) Focal cerebral ischemia in the cat: pretreatment with a competitive NMDA receptor antagonist, D-CPP-ene. J Cereb Blood Flow Metab 10:668674.

Carvalho CAM, Coutinho OP, Carvalho AP (1986) Effects of Ca channel blockers on Ca translocation across synaptosomal membranes. J Neurochem 47:1774-1784.

Clark GD, Rothman SM (1987) Blockade of excitatory amino acid receptors protects anoxic hippocampal slices. Neuroscience 21:665671 .

Cohen P, Holmes FB, Tsukitani Y (1990) Okadaic acid: a new probe for the study of cellular regulation. Trends Biol Sci 15:98-102.

Dingledine R (1983) $N$-methyl aspartate activates voltage-dependent calcium conductance in rat hippocampal pyramidal cells. J Physiol (Lond) 343:385-405.

DiPolo R, Beauge L (1988) Ca transport in nerve fibers. Biochim Biophys Acta 947:549-569.

Dubinsky JM, Rothman SM (1991) Intracellular calcium concentrations during "chemical hypoxia" and excitotoxic neuronal injury. J Neurosci 11:2545-2551.

Dykens JA, Stern A, Ekhart T (1987) Mechanism of kainate toxicity to cerebellar neurons in vitro is analogous to reperfusion tissue injury. J Neurochem 49:1222-1228.

Feig S, Lipton P (1990) N-methyl-D-aspartate receptor activation and $\mathrm{Ca}^{2+}$ account for poor pyramidal cell structure in hippocampal slices. J Neurochem 55:473-483.

Fleischer JE, Tateishi A, Drummond JC, Scheller MS, Grafe MR, Zornow MH, Shearman GT, Shapiro HM (1989) MK-801, an excitatory amino acid antagonist, does not improve neurologic outcome following cardiac arrest in cats. J Cereb Blood Flow Metab 9:795-804.

Ganong AH, Lanthorn TH, Cotman CW (1983) Kynurenic acid inhibits synaptic and amino acid-induced responses in the rat hippocampus and spinal cord. Brain Res 273:170-174.

Gietzen K, Wuthrich A, Bader H (1981) R24571: a new powerful inhibitor of red blood cell $\mathrm{Ca}^{++}$-transport ATPase and of calmodulinregulated functions. Biochem Biophys Res Commun 101:418-425.

Glohus MY-T, Dietrich WD, Busto R, Valdes I, Ginsberg MD (1989) Combined treatment with dopamine and NMDA antagonists protects against ischemic damage. Soc Neurosci Abstr 15:44.

Godfraind T, Miller R, Wibo $M$ (1986) Calcium antagonism and calcium entry blockade. Pharmacol Rev 38:321-389.

Goldberg MP, Kurth MC, Giffard RG, Choi DW (1989) 45-Calcium accumulation and intracellular calcium during in vitro "ischemia." Soc Neurosci Abstr 15:803.

Gunter TE, Pfeiffer DR (1990) Mechanisms by which mitochondria transport calcium. Am J Physiol 258:C755-C786.

Harreveld A, Ochs S (1956) Cerebral impedance changes after circulatory arrest. Am J Physiol 187:180-192.

Hata T, Makino N, Hironobu N, Yamaga T (1988) Modulation of $\mathrm{Na}-\mathrm{Ca}$ exchange in cardiac sarcolemmal vesicles by $\mathrm{Ca}$ antagonists. Mol Cell Biochem 84:65-76.

Ishizuka N, Weber J, Amaral DG (1990) Organization of intrahippocampal projections originating from CA3 pyramidal cells in the rat. J Comp Neurol 295:580-623.

Kadoyo F, Mitani A, Arai T, Kataoka K (1992) Effects of propentofylline on hypoxia-hypoglycemia-induced calcium accumulation in gerbil hippocampal slices. J Cereb Bloud Flow Metab 12:301-305.

Kass IS, Lipton P (1982) Mechanisms involved in irreversible anoxic damage to the in vitro rat hippocampal slice. J Physiol (Lond) 332: 459-472.

Kass IS, Lipton P (1986) Calcium and long-term transmission damage 
following anoxia in dentate gyrus and $\mathrm{CA} 1$ regions of the hippocampal slice. J Physiol (Lond) 378:313-334.

Kass IS, Chambers G, Cottrell JE (1989) The $N$-methyl-D-aspartate antagonists aminophosphonovaleric acid and MK-801 reduce anoxic damage to dentate granule and $\mathrm{CAl}$ pyramidal cells in the rat hippocampal slice. Exp Neurol 103:116-122.

Klcyman TR, Cragoe EJ (1988) Amiloride and its analogs as tools in the study of ion transport. J Membr Biol 105:1-21.

Kochhar A, Zivin JA, Lyden PD, Mazzarella V (1988) Glutamate antagonist therapy reduces neurologic deficits produced by focal central nervous system ischemia. Arch Neurol 45:148-153.

Korf J, Klein HC, Venema K, Postema F (1988) Increases in striatal and hippocampal impedance and extracellular levels of amino acids by cardiac arrest in freely moving rats. $J$ Neurochem 50:1087-1096.

Lee K, Frank S, Vanderklish P, Arai A, Lynch G (1991) Inhibition of proteolysis protects hippocampal neurons from ischemia. Proc Natl Acad Sci USA 88:7233-7237.

Lipton P (1988) Regulation of glycogen in the dentate gyrus of the in vitro guinea pig hippocampus; effect of combined deprivation of glucose and oxygen. J Neurosci Methods 28:147-154.

Lipton P, Lobner D (1990) Mechanisms of intracellular calcium accumulation in the CA1 region of rat hippocampus. Stroke 21(III):III60-III-64

Lipton P, Whittingham TS (1982) Reduced ATP concentration as a basis for synaptic transmission failure during hypoxia in the in vitro guinea-pig hippocampus. J Physiol (Lond) 325:51-65.

Lobner D, Lipton P (1990) Sigma-ligands and non-competitive NMDA antagonists inhibit glutamate release during cerebral ischemia. Neurosci Lett 117:169-174.

Lowry OH, Passonneau JV, Hasselberger IX, Schulz DW (1964) Effect of ischemia on known substrates and cofactors of the glycolytic pathway in brain. J Biol Chem 239:18-30.

Lust WD, Feussner GK, Burbehenn EK, Passonneau JV (1981) The enzymatic measurement of adenine nucleotides and P-creatine in picomole amounts. Anal Biochem 110:258-266.

MacDonald JF, Mody I, Salter MW (1989) Regulation of $N$-methylD-aspartate receptors revealed by intracellular dialysis of murine neurons in culture. J Physiol (Lond) 414:17-34.

Michaels RL, Rothman SM (1990) Glutamate neurotoxicity in vitro: antagonist pharmacology and intracellular calcium concentrations. J Neurosci 10:283-292.

Nicholls DG, Scott ID (1980) The regulation of brain mitochondrial calcium-ion transport. Biochem J 186:833-839.

Nicholson C (1988-89) Issues in the transmission of chemical signals through the brain extracellular space. Acta Morphol Neerl Scand 26: $68-80$

Nicotera P, Hartzell P, Baldi C, Svensson S-A, Bellomo G, Orrenius S (1986) Cystamine induces toxicity in hepatocytes through the elevation of cytosolic $\mathrm{Ca}^{2+}$ and the stimulation of a nonlysosomal proteolytic system. J Biol Chem 261:14628-14635.

O'Dell TJ, Alger BE (1991) Single calcium channels in rat guinea-pig hippocampal neurons. J Physiol (Lond) 436:739-767.

Orrenius S, McConkey DJ, Bellomo G, Nicotera P (1989) Role of $\mathrm{Ca}^{2+}$ in toxic cell killing. Trends Pharmacol Sci 10:281-285.

Pauwels PJ, Van Assouw HY, Peeters L, Leysen JE (1990) Neurotoxic action of veratridine in rat brain neuronal cultures: mechanism of neuroprotection by $\mathrm{Ca}$ antagonists nonselective for slow $\mathrm{Ca}$ channels. J Pharmacol Exp Ther 255:1117-1122.

Rader RK, Lanthorn TH (1989) Experimental ischemia induces a persistent depolarization blocked by decreased calcium and NMDA antagonists. Neurosci Lett 99:125-130.
Randall RD, Thayer SA (1992) Glutamate-induced calcium transient triggers delayed calcium overload and neurotoxicity in rat hippocampal neurons. J Neurosci 12:1882-1895.

Richard S, Diochot S, Nargeot J, Baldy-Moulinier M, Valmier J (1991) Inhibition of T-type calcium currents by dihydropyridines in mouse embryonic dorsal root ganglion neurons. Neurosci Lett 132:229-234.

Roberts EL, Sick TJ (1988) Calcium-sensitive recovery of extracellular potassium and synaptic transmission in rat hippocampal slices exposed to brief anoxia. Brain Res 456:113-119.

Schlander M, Frotscher M (1986) Non-pyramidal ncurons in the guinea-pig hippocampus. A combined Golgi-electron microscope study. Anat Embryol (Berl) 174:35-47.

Sheardown MJ, Nielsen EO, Hansen AJ, Jacobsen P, Honore T (1990) 2,3-Dihydroxy-6-nitro-7-sulfamoyl-benzo(F)quioxaline: a neuroprotectant for cerebral ischemia. Science 247:571-574.

Siemkowicz E, Hansen AJ (1981) Brain extracellular ion composition and EEG activity following 10 minutes ischemia in normo- and hyperglycemic rats. Stroke 236:239.

Siesjo BK (1988) Historical overview. Calcium, ischemia, and death of brain cells. Ann NY Acad Sci 522:638-661.

Siesjo BK, Bengtsson F (1989) Calcium fluxes, calcium antagonists, and calcium-related pathology in brain ischemia, hypoglycemia and spreading depression: a unifying hypothesis. J Cereb Blood Flow Metab 9:127-140.

Silver IA, Erecinska M (1990) Intracellular and extracellular changes of $\left(\mathrm{Ca}^{2+}\right)$ in hypoxia and ischemia in rat brain in vivo. J Gen Physiol 95:837-866.

Simon RP, Griffiths T, Evans MC, Swan JH, Meldrum BS (1984) Calcium overload in selectively vulnerable neurons of the hippocampus during and after ischemia: an electron microscope study in the rat. J Cereb Blood Flow Metab 4:350-361.

Sloviter RS (1989) Calcium-binding protein (calbindin-D28) and parvalbumin immunocytochemistry: localization in the rat hippocampus with specific reference to the selective vulnerability of hippocampal neurons to seizure activity. J Comp Neurol 280:183-196.

Smith MW, Phelps PC, Trump BF (1991) Cytosolic Ca deregulation and blebbing after $\mathrm{HGC} 12$ injury to cultured rabbit proximal tubule cclls as detcrmincd by digital imaging microscopy. Proc Natl $\Lambda$ cad Sci USA 88:4926-4930.

Suszkiw JB, Murawsky MM, Shi M (1989) Further characterization of phasic calcium influx in rat cerebrocortical synaptosomes: inferences regarding calcium channel type(s) in nerve endings. J Neurochem 52:1260-1269.

Uematsu D, Arki N, Greenberg JH, Sladky J, Reivich M (1991) Combined therapy with MK-801 and nimodipine for protection of ischemic brain damage. Neurology 41:88-94.

Vaghy PL, Johnson JD, Matlib MA, Wang T, Schwarz A (1982) Selective inhibition of $\mathrm{Na}$-induced $\mathrm{Ca}$ release from heart mitochondria by diltiazem and certain other Ca antagonist drugs. J Biol Chem 257: $6000-6002$.

Weiss J, Goldberg MP, Choi D (1986) Ketamine protects cultured ncocortical ncurons from hypoxic injury. Brain Res 380:186-190.

Westenbroek RE, Ahlijanian MK, Caterall WA (1990) Clustering of L-type channels at the base of major dendrites in hippocampal pyramidal neurons. Nature 347:281-284.

Whittingham TS, Lust WD, Passonneau JV (1984) An in vitro model of ischemia: metabolic and electrical alterations in the hippocampal slice. J Neurosci 4:793-802.

Wong EHF, Knight AR, Woodruff GN (1988) ['H]MK-801 labels a site on the $N$-methyl-D-aspartate receptor channel complex in rat brain membranes. J Neurochem 50:274-281. 